\title{
Molecular epidemiology of respiratory viruses in commercial chicken flocks in Pakistan from 2014 through to 2016
}

\author{
Sajid Umar ${ }^{1,2}$, Angélique Teillaud ${ }^{1}$, Hassan Bin Aslam³ ${ }^{3}$ Jean-Luc Guerin ${ }^{1}$ and Mariette F. Ducatez ${ }^{1 *}$ (D)
}

\begin{abstract}
Background: Viral diseases are a matter of great concern for poultry farmers in Pakistan. Multiple common viral respiratory diseases (CVRDs) cause huge economic losses in the poultry industry. The prevalence of CVRDs in many countries, including Pakistan, is not clearly understood.

Results: Incidences of 5 chicken respiratory viruses: avian influenza virus (AIV), Newcastle disease virus (NDV/AAW-1), infectious bronchitis virus (IBV), avian metapneumovirus (aMPV) and infectious laryngotracheitis virus (ILTV) were assessed on commercial Pakistani farms with respiratory problems from 2014 through to 2016. While AlV and AAW-1 were frequently detected (16 to $17 \%$ of farms), IBV and aMPV were rarely detected (in 3 to $5 \%$ of farms) and ILTV was not detected. We characterized H9 AIV of the G1 lineage, genotype VII AAW-1, GI-13 IBV, and type B aMPV strains with very little genetic variability in the 2-year study period. Co-infections with AIV and AAW-1 were common and wild type AAW1 was detected despite the use of vaccines. Control measures to limit the virus burden in chicken flocks are discussed.

Conclusions: Our data shows that AIV (H9), AAW-1, IBV and aMPV are prevalent in commercial poultry in Pakistan. Further studies are necessary to assess circulating strains, economic losses caused by infections and coinfections of these pathogens, and the costs and benefits of countermeasures. Furthermore, veterinarians and farmers should be informed of the pathogens circulating in the field and hence advised on the use of vaccines.
\end{abstract}

Keywords: Chicken respiratory viruses, Molecular epidemiology, Chicken, Pakistan, Avian influenza virus, Infectious bronchitis virus, Newcastle disease virus, Avian metapneumovirus

\section{Background}

Commercial poultry in Pakistan was established in the early 1960s, representing one of the largest agriculturebased segments of Pakistan's economy with a significant contribution to national gross domestic product (1.3\%) [1]. There are over 25,000 poultry farms spread across the country's rural areas and the Pakistan poultry industry produces around 1220 million $\mathrm{kg}$ of chicken meat and 10,000 million eggs a year [2]. In the past, regional studies on poultry disease surveillance and clinical surveys have been conducted to better understand the disease distribution pattern in different regions of Pakistan [3-5]. Recently, outbreaks of viral diseases with high morbidity and mortality were being reported consistently

\footnotetext{
* Correspondence: m.ducatez@envt.fr

${ }^{1}$ IHAP, Université de Toulouse, INRA, ENVT, 23 Chemin des Capelles, 31076

Toulouse, France

Full list of author information is available at the end of the article
}

[6-8] and are possibly due to the intensification of commercial poultry production and lack of biosecurity measures. Pakistan's poultry industry has indeed been growing continuously, facilitating the spread of multiple common viral respiratory diseases (CVRDs) such as Newcastle disease (ND), infectious bronchitis (IB), swollen head syndrome (SHS), infectious laryngotracheitis (ILT) and low pathogenic avian influenza (LPAI) infections, which are caused by Avian Avulavirus 1 (AAVV-1), infectious bronchitis virus (IBV), avian metapneumovirus (aMPV), infectious laryngotracheitis virus (ILTV) and avian influenza virus (AIV), respectively. These are highly contagious diseases of poultry, with worldwide distribution and they have serious economic impacts on the poultry industry. The causative agents of these diseases affect chickens of all ages except ILTV, which normally does not affect chickens before 3 weeks of age. These pathogens may interact with bacterial agents resulting in 
high morbidity and mortality in the infected chickens [9]. The continuous emergence of new virulent genotypes from global epidemics and the frequent changes observed in the genomic sequence of these viruses lead to ineffective diagnostics and control measures. Outbreaks of CVRDs such as IB and SHS are not reported to the country's ministry in charge of livestock and poultry production. Consequently, the distribution patterns of such chicken diseases are unclear in Pakistan [3]. Moreover, CVRDs, such as LPAI (H9N2), are of great significance to public health due to their zoonotic potential [10-12]. Therefore, it is important to investigate the distribution pattern of CVRDs in different regions and different chicken production types to develop scientific and riskbased prevention measures of these poultry diseases.

The aim of this study was to detect and characterize chicken respiratory viruses found in commercial Pakistan poultry, which is the first step of control measures implementation. Five major chicken respiratory viruses were investigated: AIV, AAVV-1, IBV, aMPV and ILTV.

\section{Results}

Virus prevalence and co-infections in Pakistanis farms

In Pakistan, samples were screened for viral respiratory pathogen nucleic acid within the commercial broiler and layer hen populations. Viral respiratory diseases are common even though vaccines are being used on a small scale in the country. In total, 161 pooled samples from 89 flocks were collected during 2014-2016 from different areas of Pakistan. Among these flocks, there were 15 (16.8\%) positives for AIV (H9), 16 positives for AAVV-1 (17.9\%), 4 positives for IBV (4.4\%), and 2 positives for aMPV (2.2\%). No ILTV positive sample was detected in our study (Fig. 1). Co-infections were common for AIV and AAVV-1 (9 AIV/ AAVV-1 coinfected flocks) but less common for the other avian viruses of interest (Table 1). Briefly, 9 flocks $(6,21,23$, $38,41,42,66,67,68$ ) were found positive for AIV (H9) and AAVV-1 coinfections. AAVV-1 + aMPV, AIV + aMPV and AAVV-1 + IBV coinfections were detected only in flock number 69,70 and 80 , respectively. There was no observed difference in the likelihood of coinfection between production types.

Molecular epidemiology of avian influenza virus in Pakistan Twenty-two of the 161 collected samples were PCR positive for AIV. Partial HA sequences were obtained for 19 Pakistani strains; they were all identical but one. They all clustered with H9 influenza viruses. A/chicken/Pakistan/ $17 / 2014$ and A/chicken/Pakistan/74/2015 were selected as

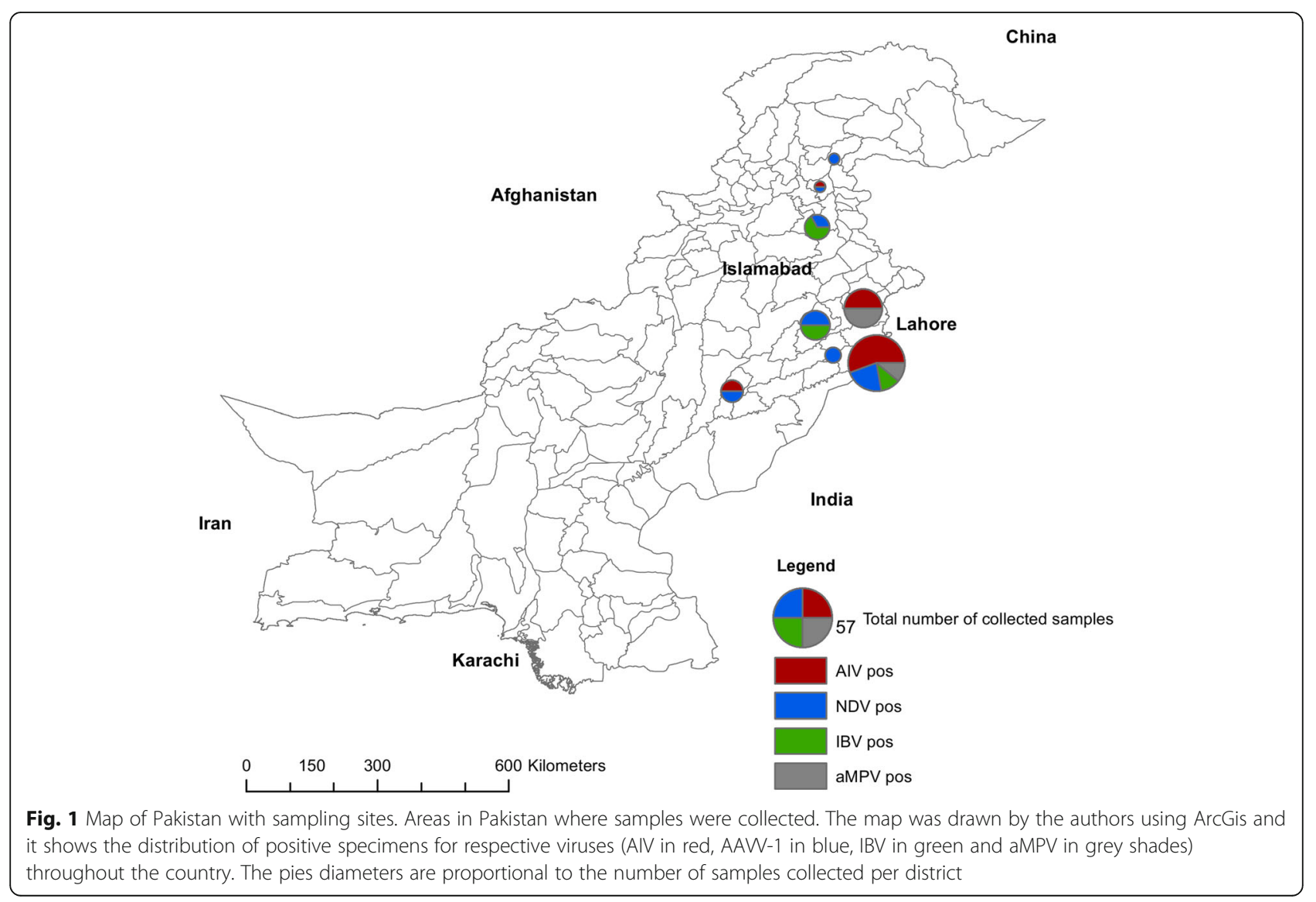




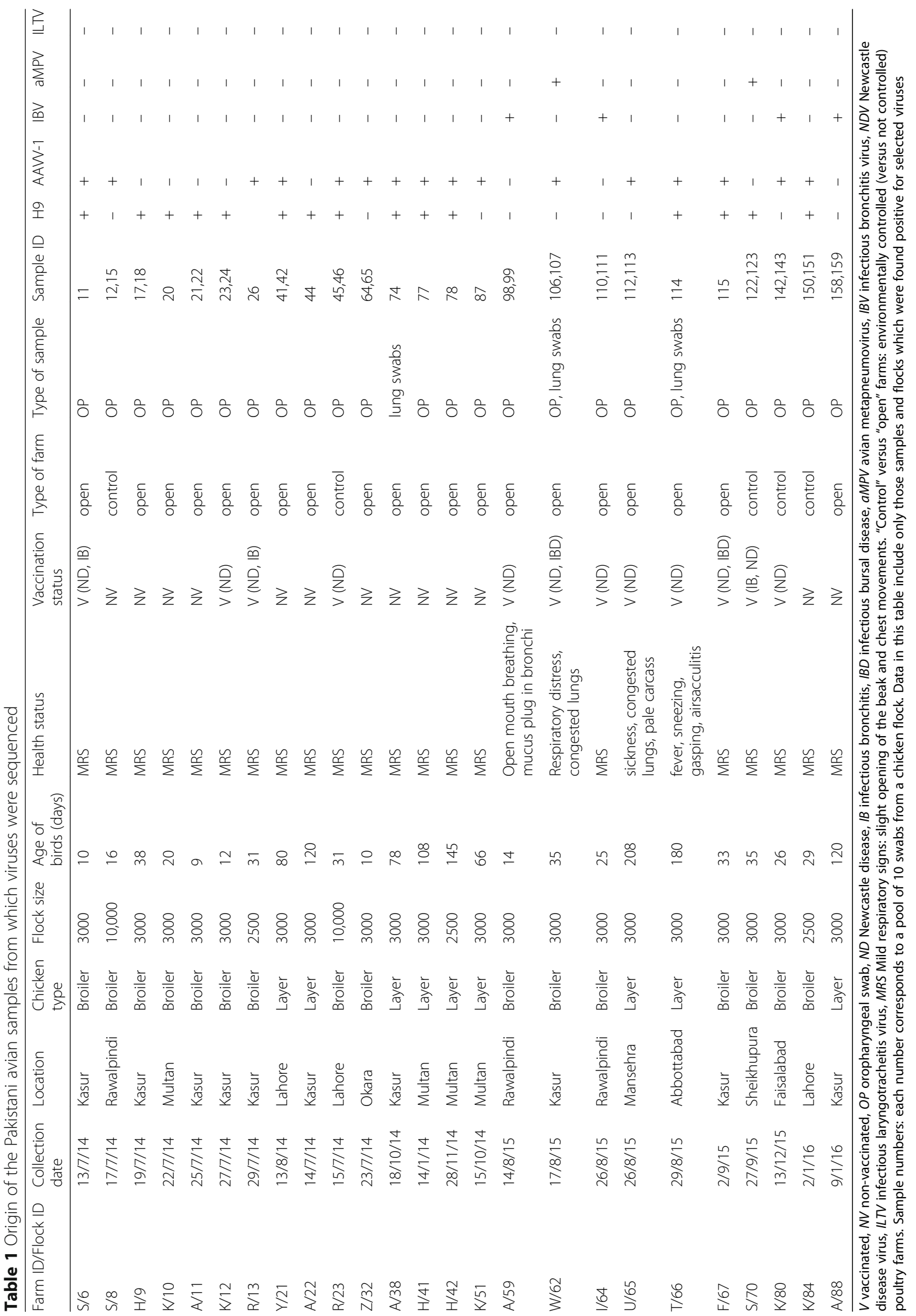


representative sequences of 2014-2016 Pakistani samples. They cluster with G1-like viruses and are closely related to strains from Libya, Tunisia, Saudi Arabia and Pakistan, collected from 2005 through to 2015 (Fig. 2).
Molecular epidemiology of avian avulavirus-1 in Pakistan Nineteen of the 161 collected samples were AAVV-1 PCR positive. A total of 9 partial $F$ gene sequences were phylogenetically compared with representatives of the 18

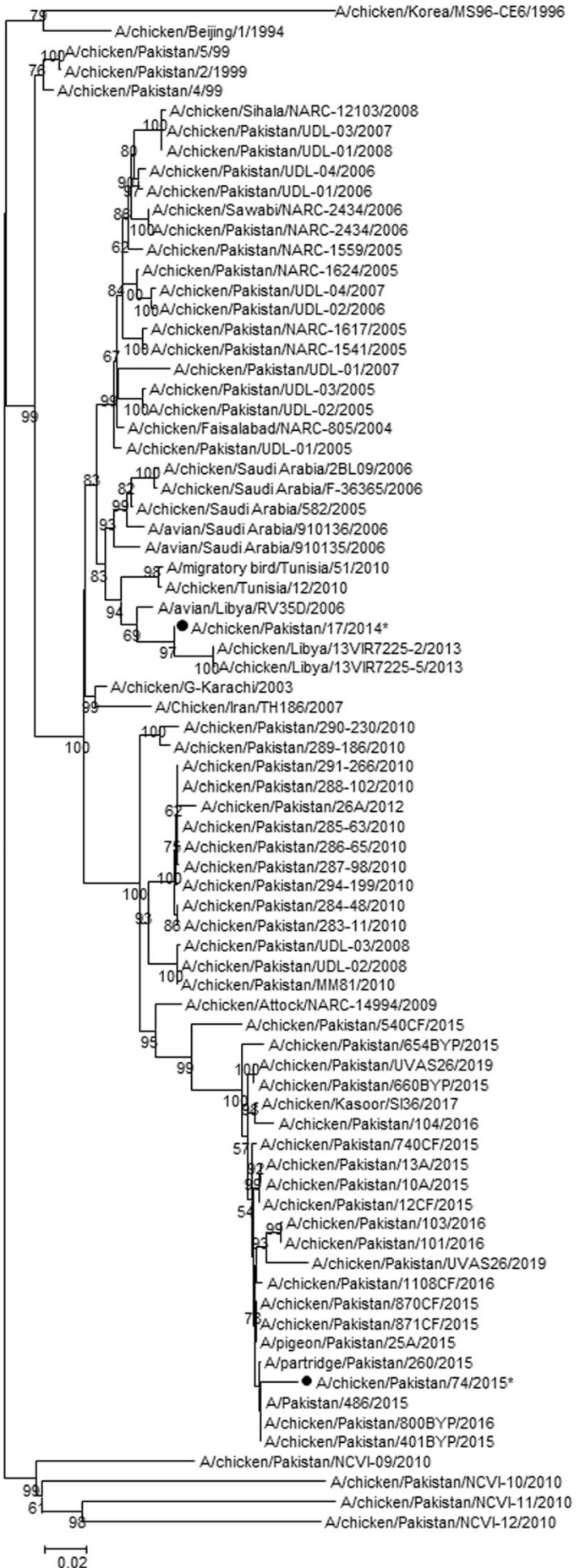

Fig. 2 Maximum Likelihood Phylogenetic tree of recent Pakistani influenza viruses HA gene sequences. Sequences of A/chicken/Pakistan/17/2014 and A/chicken/Pakistan/74/2015 were selected as representative sequences for the present study. The HA2 nucleotide sequences of these 2 viruses are indicated in bold font with a closed circle shaped symbol. *: partial sequence 
known AAVV-1 genotypes that circulate worldwide. The 9 Pakistani AAVV-1 sequences were identical; therefore, AAVV-1/chicken/Pakistan/11/2014 were used as a representative sequence for analysis. Pakistani AAVV-1 strains $F$ protein cleavage site amino acid sequences, GRRQKR*F (aa 111-117), were indicative of high viral virulence. The phylogenetic tree clearly shows that AAVV-1/chicken/Pakistan/11/2014 clusters with sequences of genotype VII viruses (supported by a 100 bootstrap value, Fig. 3).

\section{Molecular epidemiology of infectious bronchitis virus in Pakistan}

Eight of the 161 collected samples were PCR positive for IBV. A total of 8 partial S1 gene sequences were phylogenetically compared with representatives of the 32 viral IBV genotypes circulating worldwide. As the 8 Pakistani IBV sequences were identical, $\gamma \mathrm{CoV} /$ chicken/ Pakistan/142/2015 was selected as a representative strain. $\gamma \mathrm{CoV} /$ chicken/Pakistan/142/2015 clusters with genotype 1 lineage 13 viruses, previously called 793/B or 4/91 genotype. This is supported by a very high bootstrap value (100) (Fig. 4).

\section{Molecular epidemiology of avian metapneumovirus in Pakistan}

Four of the 161 collected samples were aMPV PCR positive. A total of 4 partial G gene sequences were obtained, all identical, and aMPV/chicken/Pakistan/107/2015 (representative Pakistani sequence) was phylogenetically compared with representatives of the 4 known aMPV genotypes (A to D). The Pakistani sequence clusters with aMPV type B viruses (Fig. 5).

\section{Discussion}

Viral infections of poultry cause considerable economic loss and respiratory viruses are frequently reported as primary or secondary pathogens of poultry worldwide. This work focused on the prevalence and molecular

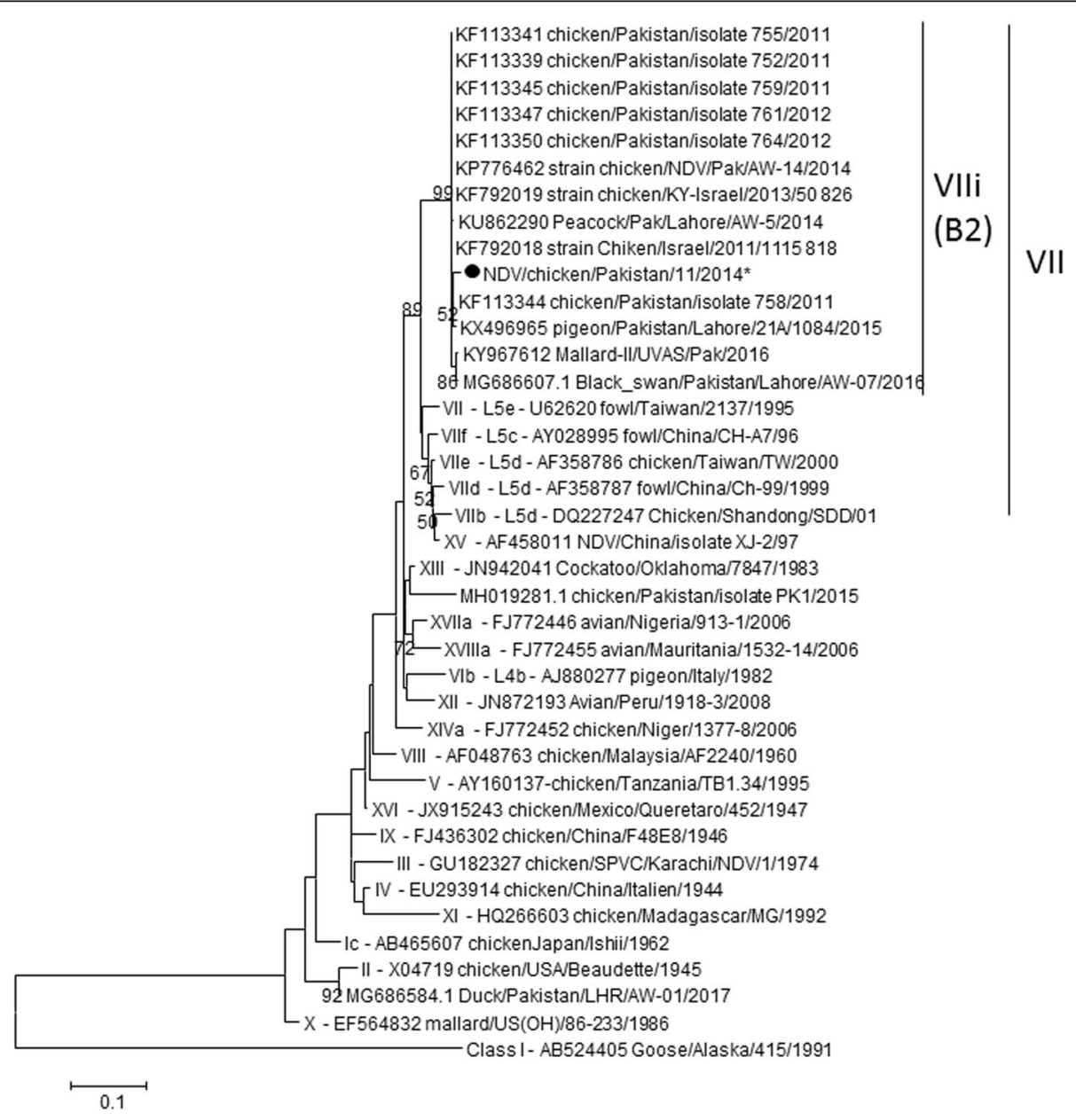

Fig. 3 Maximum Likelihood Phylogenetic tree of recent Pakistani Newcastle disease viruses partial F gene sequences. Sequences of Pakistanis AAW-1 were identical and AAW-1/chicken/Pakistan/11/2014 was selected as a representative strain for the present study. *: partial sequence 


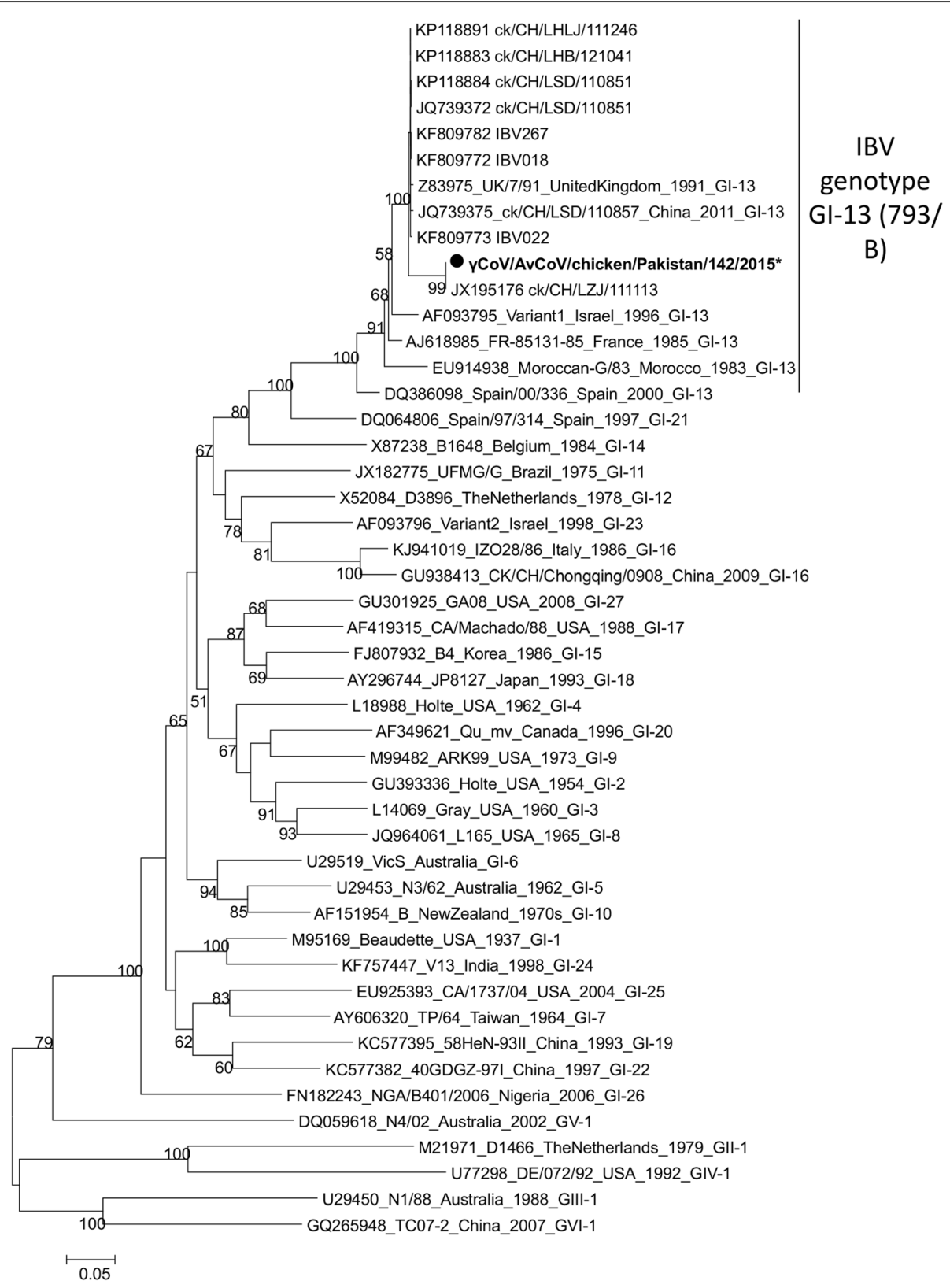

Fig. 4 Maximum Likelihood Phylogenetic tree of recent Pakistani infectious bronchitis viruses spike gene sequences. Sequences of $\gamma \mathrm{CoV} / \mathrm{AvCoV/}$ chicken/Pakistan/11/2014, үCoV/AvCoV/chicken/Pakistan/98/2015, үCoV/AvCoV/chicken/Pakistan/99/2015, үCoV/AvCoV/chicken/Pakistan/142/2016, YCoV/AvCoV/chicken/Pakistan/143/2016, and YCoV/AvCoV/chicken/Pakistan/159/2016 were identical so only YCoV/AvCoV/chicken/Pakistan/142/ 2016 was represented on the tree with a black circle shaped symbol. *: partial sequence

epidemiology of viral respiratory pathogens within the Pakistani commercial broiler and layer hen populations.

AIV has been frequently reported in Pakistan since 1994. LPAI H9N2, LPAI and HPAI H7N3 and HPAI H5N1 viruses have been regularly identified. Two LPAI H4N6 viruses from 2010 and 2011 have been isolated and sequenced. LPAI H9N2 and HPAI H7N3 were isolated from the same flock in 2003 [13] and since then frequent reassortment events between H7N3, H5N1 and
H9N2 have been reported [10, 14]. Recently, H9N2 virus was isolated in $5.7 \%$ of 905 tested flocks of commercial and backyard poultry in Pakistan. Hemagglutinin and neuraminidase-gene-based phylogenetic analysis of commercial and backyard poultry isolates showed 100\% homology within sub-lineage B2 of Pakistan [11]. The G1-like viruses detected here were closely related to previously characterized strains from Libya, Tunisia, Saudi Arabia and Pakistan. Considering the geographic proximity of 


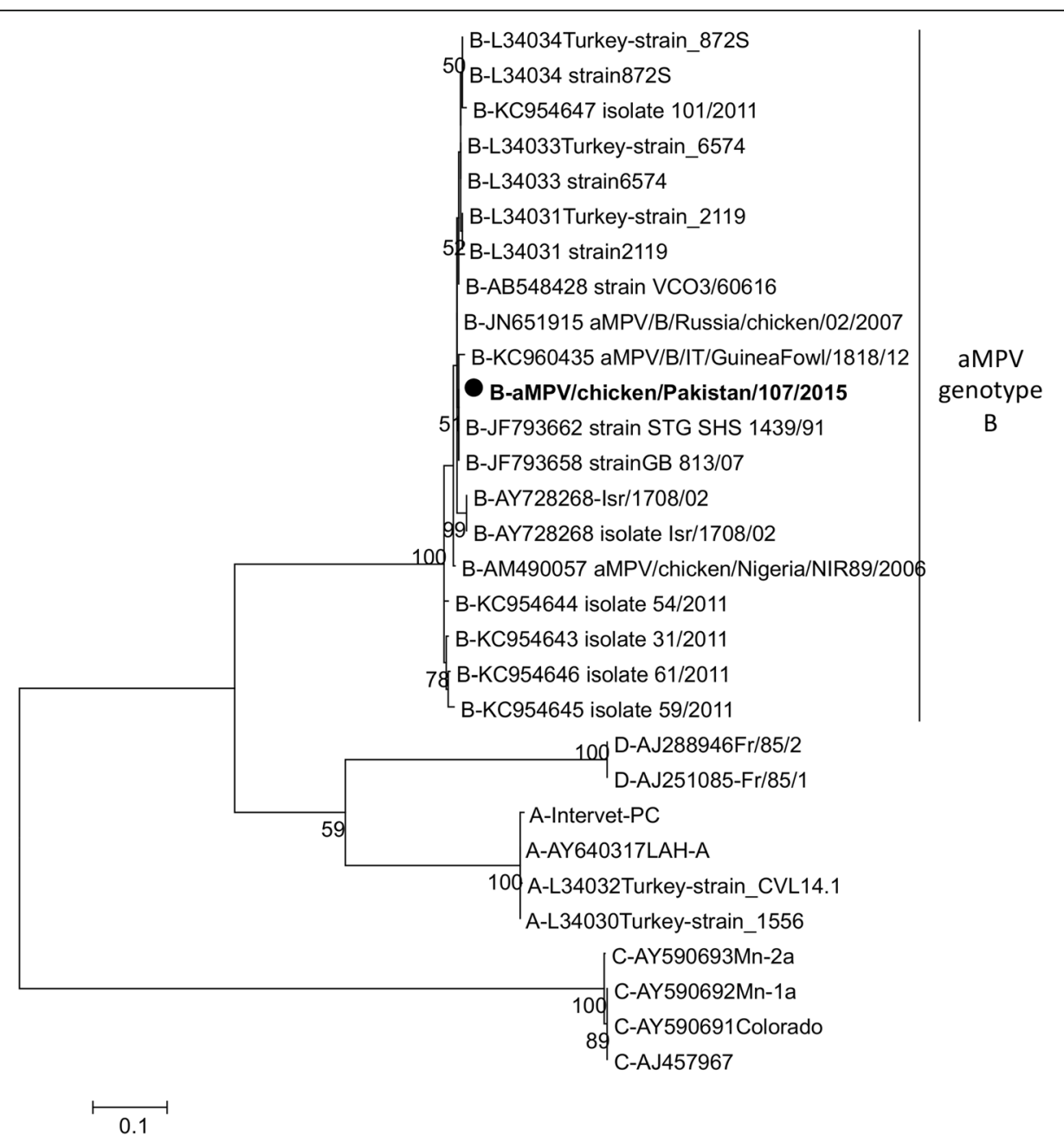

Fig. 5 Maximum Likelihood Phylogenetic tree of recent Pakistani avian metapneumoviruses attachment protein gene sequences. Sequences of aMPV/chicken/Pakistan/106/2015, aMPV/chicken/Pakistan/107/2015, aMPV/chicken/Pakistan/122/2016, and aMPV/chicken/Pakistan/123/2016 were identical so only aMPV/chicken/Pakistan/107/2015 was represented on the tree with a black circle shaped symbol. The 4 genotypes were included here: A, B, C, and D and genotype B strains are clearly indicated on the right-hand side of the tree

these countries and the commercial exchanges, it is not surprising that these strains were detected in Pakistan.

In the present study, LPAI H9 virus was detected on several Pakistani farms from 2014 through to 2016. It would be interesting to conduct further molecular characterization to confirm that only $\mathrm{H} 9$ is present, link clinical signs to genes constellations, and to better understand the role of molecular determinants of field pathogenicity of currently circulating $\mathrm{H} 9$ viruses in unvaccinated flocks. Unfortunately, the method used to collect samples did not allow the isolation of the viruses. This resulted in limited nucleic acid quantities that did not allow for the amplification of more than the HA2 part of the genome. Similarly, only partial gene sequences were obtained for AAVV-1, IBV, and aMPV. Regardless, the circulating subtypes/genotypes of chicken viruses in Pakistan were as follows: genotype VII AAVV-1 (VIIi), GI-13 (793B) IBV and genotype B aMPV, with no difference from the summer of 2014 through to January 2016.

Avian avulavirus 1 (AAVV-1) is a member of the genus Avulavirus of the family Paramyxoviridae. The AAVV-1 species include multiple strains of avian paramyxovirus 1 (APMV-1) virus. APMV-1 is of particular importance to poultry due to virulent strains which cause Newcastle disease, often referred to as Newcastle disease viruses (AAVV-1 s). At least two classes and 18 genotypes of AAVV-1 have been described. Despite the use of imported vaccines, AAVV-1 still remains the main poultry disease in both commercial and rural chickens flocks of Pakistan [15]. Recently, AAVV-1 s of genotype VI, VII and XIII were detected in Pakistani poultry [16-23] and genotype VII is predominant across the country. Similarly, Miller et al. [24] reported that viruses of sub-genotype VIIi have replaced AAVV-1 isolates of genotype XIII in Pakistan, 
which were commonly isolated since 2009-2011. The viruses of genotype VII had a high genetic diversity as compared to isolates from genotypes VI and XIII and, therefore, have more potential to evolve over a period of time [25]. Partial sequences for the F gene were used for construction of phylogeny tree, which is a clear limitation of this study. Full $\mathrm{F}$ gene sequences would allow for a more detailed phylogeny of circulating strains of AAVV-1 in Pakistan.

Direct comparison of the IBV and aMPV findings with previous Pakistani ones is not possible due to the absence of published data. There has been so far no genomic characterization of IB viruses circulating in Pakistan, but there is serological evidence of the pathogen. Ahmed et al. [25] showed seroprevalences of IBV strains M-41 (88\%), D-274 (40\%), D-1466 (52\%), and 491 (8\%) in Pakistani poultry. Massachusetts strains (such as M41) are mainly used as vaccines in the field in Pakistan but we cannot totally rule out the use of 4-91 vaccines due to the limited control of imported vaccines. Similarly, high prevalence of IBV in backyard poultry (74\%) and commercial poultry of Bangladesh (57\%) were reported [26]. Sumi et al. [27] classified Indian IBV isolates based on phylogenetic analysis within the Mass genotype (India/LKW/56/IVRI/08, now called GI-1) and the 793/B genotype (or 4-91 genotype, India/NMK/72/IVRI/10, now called GI-13). Moreover, IBV viruses of genotype 793/B-like (GI-13) and QX-like (GI-19) have been reported recently in poultry of Iran and Iraq $[28,29]$. Considering the geographic proximity of the 5 countries and the commercial exchanges, it is not surprising that $793 / \mathrm{B}$ (GI-13) strains were detected in Pakistan.

High seroprevalence of aMPV in broiler (48\%) and breeder (93\%) flocks has been reported in Iran [30]. In a recent study in Ahwaz, in the south west of Iran, Mayahi and colleagues reported 55.5\% aMPV seropositivity [31]. Similarly, Eswaran et al. reported seroprevalence of aMPV in breeders (34\%) of Tamil Nadu in India [32]. The virus has clearly circulated in the region. aMPV subtype $B$ have been reported in Iran [33, 34]. In addition, aMPV subtype A and subtype C have been reported in China [35-37]. Again, geographic proximity and commercial exchanges of Pakistan with Iran and India rather than with China may explain the circulation of aMPV type B in Pakistan, although the PCR primers used here would not have allowed aMPV subtype $\mathrm{C}$ detection.

While most of the sampled farms did not vaccinate against any of the chicken viruses of interest, putative AAVV-1 vaccine failures were observed in farms $6,13,23$, $62,65,66,67$, and 80 (Table 1). The AAVV-1 vaccines used in Pakistan are the LaSota (genotype II) and R2B (mesogenic Mukteswar strain, genotype III) strains. Field AAVV-1 detected in the present study (genotype VII) were therefore not vaccine viruses. The LaSota vaccine is formulated from a lentogenic (low virulence) clone of the LaSota strain and is manufactured in different countries around the world. The vaccine is imported to Pakistan and administered to commercial poultry flocks. In contrast, the R2B strain is manufactured by local vaccine companies and administered to backyard poultry. It is still unknown whether these vaccine strains (genotypes II and III viruses) can elicit a protective immune response against the prevailing field strains, especially genotype VII viruses: the protection should be evaluated in experimental and field conditions. Furthermore, the inability of live vaccines to elicit a protective immune response might be due to an inadequate cold chain supply system, inappropriate route of vaccination, or incorrect vaccination schedules. It has been reported that the currently applied AAVV-1 vaccines give better protection against the velogenic AAVV-1 s isolated from the 1930s through to the 1970s (Herts33/56, California 71) than those more recently isolated [38]. Hence parameters for selection of vaccine strains need to be reconsidered. Likewise, the optimization of vaccination schedules according to local climate and environmental conditions should be investigated.

The present study helps to understand the virus burden of Pakistani poultry production systems and highlights frequent AIV/AAVV-1 co-infections. This phenomenon has been observed previously in Bangladesh [39]. This finding may be explained by both the endemic status of the two viruses in Pakistani poultry and the poor biosecurity on farms, favoring the emergence of multiple pathogens. Experimental co-infections with the AIV and AAVV-1 showed little impact on clinical signs but altered virus shedding (with higher LPAIV than AAVV-1 shedding) $[40,41]$.

The main limitations of this study are (i) the type of samples collected (no virus isolation is possible from FTA cards), (ii) the thus limited amount of viral nucleic acids, and (iii) the limited knowledge available on most avian viruses circulating in the country for comparison. Further studies are warranted to fully characterize the virus strains and evaluate vaccines efficacy to counter the different pathogens.

\section{Conclusions}

Our data showed that AIV (H9), AAVV-1, IBV and aMPV were prevalent in Pakistani commercial poultry flocks. Further studies are necessary to assess circulating strains, economic losses due to infections and coinfections, and the costs and benefits of control measures. Furthermore, veterinarians and farmers should be informed of the pathogens circulation in the field and hence advised on the use of vaccines. 


\section{Methods}

\section{Sample collection}

From July 2014 through January 2016, 89 commercial poultry farms (broiler and layer farms) were sampled at different locations in Pakistan by participating veterinarians (Fig. 1). In total, 161 samples were collected. Sampling areas were chosen based on poultry population size: the selected sampling area is Pakistan's main poultry producing region (with more than $50 \%$ of the country's poultry farms, [42, 43], (Dr. Umar and Bin Aslam, personal communications). Farms were selected based on reports of clinical respiratory signs from the farmers to their veterinarians. The reported clinical signs were as follows (at least 2 signs needed to be included in the study): mortality, and/or drop in egg production, and/or drop in feed and water consumption, and/or nasal/eye discharge, and/or labored breathing, and/or gasping. Birds were sampled by trained personnel (a veterinarian with the help of the farmers who were trained on this occasion on how to swab birds) and flocks were excluded when the onset of clinical signs was observed more than 4 days prior to the visit. Farms were sampled once only (no repeated sampling). Oropharyngeal swabs or tissue impression smears (trachea, lungs) from birds showing respiratory signs were blotted onto Finders Technology Associates (FTA ${ }^{\oplus}$ ) sampling cards (Whatman, Inc., Clifton, NJ). The FTA cards were allowed to air dry and were stored at $4{ }^{\circ} \mathrm{C}$ until further processing. Age, flock size and health status are summarized in Table 1. For each flock, 1 or 2 FTA cards were used, and 10 swabs were blotted on each FTA card at the farm (one sample number refers to a pool of 10 swabs from symptomatic birds in a given flock, Table 1) to detect a prevalence of $\geq 0.14$ to $\geq 0.28 \%$ for each virus per flock (for flocks of 2500 to 10,000 birds with a 95\% confidence level). According to the farmers' information, some of the farms had been vaccinated against ND, infectious bursal disease and/ or IB, but none of the farms visited had been vaccinated against aMPV or ILTV (Table 1).

\section{RNA-DNA isolation}

Discs $(3 \mathrm{~mm})$ from FTA cards were incubated at $4{ }^{\circ} \mathrm{C}$ for $24 \mathrm{~h}$ in $1 \mathrm{~mL}$ of phosphate- buffered saline (PBS).

A comparative pilot experiment using both the QIAamp Viral RNA isolation and DNA isolation kits (Qiagen Germany) according to the instructions of the manufacturer with infectious bursal disease virus (IBDV, RNA virus) and infectious laryngotracheitis virus (ILTV, DNA virus) vaccines was performed. Real-time (RT)PCRs were then carried out to compare the extracted material and the results were as follows: (i) extracting ILTV DNA with the QIAamp viral RNA isolation kit resulted in a loss of $1 \mathrm{Ct}$ value (a twofold difference in viral DNA copies), as compared to the DNA isolated with the DNA extraction kit; (ii) extracting IBDV RNA with the Qiagen DNA extraction kit resulted in a loss of $3 \mathrm{Ct}$ values (a tenfold difference in viral RNA copies), as compared to the RNA isolated with the RNA extraction kit. We therefore considered that the loss of sensitivity in detecting the DNA virus was negligible and that we could use the QIAamp Viral RNA isolation kit to extract both RNA and DNA. Viral RNA and DNA from FTA cards were therefore extracted using the QIAamp $^{\oplus}$ viral RNA isolation kit (Qiagen, Germany) following the manufacturer's instructions. RNA/DNA was eluted in $50 \mu \mathrm{L}$ elution buffer and stored at $80{ }^{\circ} \mathrm{C}$ until further use.

\section{Reverse transcriptions (RT) and polymerase chain reactions (PCR)}

Complementary DNA (cDNA) was generated for RNA viruses from $5 \mu \mathrm{L}$ of extracted RNA using RevertAid first strand cDNA synthesis kit (RevertAid First Strand cDNA Synthesis kit, ThermoFisher Scientific, Carlsbad, CA) following the manufacturer's protocol. Briefly, $5 \mu \mathrm{L}$ of total RNA was mixed with random hexamer primers $(0.3 \mu \mathrm{g} / \mu \mathrm{L})$ and incubated for $5 \mathrm{~min}$ at $65^{\circ} \mathrm{C}$. Then, $4 \mu \mathrm{L}$ of $5 \mathrm{x}$ reaction buffer (ThermoFisher Scientific, Carlsbad, CA), $0.5 \mu \mathrm{L}$ of RNase Out (Life Technologies, Carlsbad, $\mathrm{CA}), 2 \mu \mathrm{L}$ of $10 \mathrm{mmol} / \mathrm{L}$ deoxynucleoside triphosphate (dNTP) solution (Finnzymes, Espoo, Finland), and $1 \mu \mathrm{L}$ of RevertAid reverse transcriptase (ThermoFisher Scientific, Carlsbad, CA) were added. Water was added to reach a final reaction volume of $20 \mu \mathrm{L}$. The $\mathrm{RT}$ reaction was completed following $10 \mathrm{~min}$ at $25^{\circ} \mathrm{C}$ then $60 \mathrm{~min}$ at $42{ }^{\circ} \mathrm{C}$, and finally $10 \mathrm{~min}$ at $70^{\circ} \mathrm{C}$. cDNA was used as the template for PCR amplification. The primers and PCR conditions used for the detection of AAVV-1, IBV, aMPV (types A and B), ILTV, and AIV are listed in Table 2. Two different Taq DNA Polymerases were used in this study (Qiagen Taq DNA polymerase, Germany, for the 2014 samples; and Kapa biosystems, Inc. MA, for the 2015-2016 samples). All PCR programs were performed with a GeneAmp PCR system 9700 thermal cycler (Applied Biosystems, USA). PCR amplicons were analysed using $1.5 \%$ agarose gels (Ultrapure, Invitrogen, Merelbeke, Belgium), containing nucleic acid stain $\left(\right.$ SYBR $^{\odot}$ Safe DNA gel stain, ThermoFisher Scientific, Carlsbad, CA) and using $1 \times \mathrm{TBE}$ as electrophoresis running buffer. Bands sizes were compared to a commercially available $100 \mathrm{bp}$ ladder (Bioline HyperLadder ${ }^{\mathrm{Tm}} 100$ bp). Attenuated live vaccine viruses: Newcastle Disease Vaccine B1 Type LaSota Strain (Merial) for AAVV-1, MassH120 (Bioral H120) for IBV, Nobilis TRT (MSD) for aMPV, and A/turkey/Italy/977/99(H7N1) for AIV were used as positive controls. Negative (RNAse/DNAse free $\mathrm{H}_{2} \mathrm{O}$ ) controls were included in each reaction. 
Table 2 PCR conditions for the detection and genotyping of avian respiratory viruses in samples from Pakistan

\begin{tabular}{|c|c|c|c|c|c|c|c|}
\hline Virus & & Primers & Sequences (5-3) & Target & $\begin{array}{l}\text { Amplicon } \\
\text { size (bp) }\end{array}$ & PCR conditions & Reference \\
\hline \multirow{9}{*}{$\begin{array}{l}\text { Detection } \\
\text { PCR }\end{array}$} & \multirow[t]{2}{*}{ AAW-1 } & FIP-1 & 5' TACTTTGCTCACCCCCCTT 3' & \multirow[t]{2}{*}{ Fusion gene (F) } & \multirow[t]{2}{*}{280} & \multirow{2}{*}{$\begin{array}{l}94 \mathrm{C} \text { for } 2 \text { min; } 40 \text { cycles } \\
\text { of } 94 \mathrm{C} \text { for } 30 \mathrm{~s}, 58 \mathrm{C} \\
\text { for } 30 \mathrm{~s}, 72 \mathrm{C} \text { for } 1 \mathrm{~min} \text {; } \\
\text { final extension at } 72 \mathrm{C} \\
\text { for } 5 \text { min }\end{array}$} & \multirow[t]{2}{*}{ [48] } \\
\hline & & FIP-2 & 5' CATCTTCCCAACTGCCACT 3' & & & & \\
\hline & \multirow[t]{2}{*}{ IBV } & N791 & $5^{\prime}$ GTGATGACAAGATGAATGAGGA $3^{\prime}$ & \multirow{2}{*}{$\begin{array}{l}\text { Nucleo-protein } \\
\text { gene }(\mathrm{N})\end{array}$} & \multirow[t]{2}{*}{380} & \multirow{2}{*}{$\begin{array}{l}94 \mathrm{C} \text { for } 2 \mathrm{~min} ; 40 \text { cycles } \\
\text { of } 94 \mathrm{C} \text { for } 30 \mathrm{~s}, 54 \mathrm{C} \text { for } \\
30 \mathrm{~s}, 72 \mathrm{C} \text { for } 1 \mathrm{~min} \text {; final } \\
\text { extension at } 72 \mathrm{C} \text { for } 5 \mathrm{~min}\end{array}$} & \multirow[t]{2}{*}{ [49] } \\
\hline & & N1129 & 5' CAGCTGAGGTCAATGCTITATC 3' & & & & \\
\hline & ILTV & $\begin{array}{l}\text { gEU } \\
\text { gEL }\end{array}$ & $\begin{array}{l}\text { 5' GCTGGGTTCTGGGCTACACAAC 3' } \\
\text { 5' TGCGCGTGACTCGGAGAG 3' }\end{array}$ & $\begin{array}{l}\text { Glyco-protein E } \\
\text { gene (gE) }\end{array}$ & 626 & $\begin{array}{l}94 \mathrm{C} \text { for } 2 \mathrm{~min} ; 40 \text { cycles } \\
\text { of } 94 \mathrm{C} \text { for } 30 \mathrm{~s}, 61 \mathrm{C} \text { for } \\
30 \mathrm{~s}, 72 \mathrm{C} \text { for } 1 \mathrm{~min} \text {; final } \\
\text { extension at } 72 \mathrm{C} \text { for } 5 \mathrm{~min}\end{array}$ & {$[50]$} \\
\hline & \multirow[t]{2}{*}{ aMPV } & $\mathrm{G} 1^{\mathrm{a}}$ & 5' GGGACAAGTATCYMKAT 3' & \multirow{2}{*}{$\begin{array}{l}\text { Attachment } \\
\text { glycoprotein } \\
\text { gene }(G)\end{array}$} & \multirow[t]{2}{*}{441} & \multirow{2}{*}{$\begin{array}{l}94 \mathrm{C} \text { for } 2 \text { min; } 40 \text { cycles } \\
\text { of } 94 \mathrm{C} \text { for } 30 \mathrm{~s}, 50 \mathrm{C} \text { for } \\
30 \mathrm{~s}, 72 \mathrm{C} \text { for } 1 \mathrm{~min} \text {; final } \\
\text { extension at } 72 \mathrm{C} \text { for } 5 \mathrm{~min}\end{array}$} & \multirow[t]{2}{*}{ [51] } \\
\hline & & $\mathrm{G}^{\mathrm{a}}$ & 5' CTGACAAATTGGTCCTGATT 3' & & & & \\
\hline & \multirow[t]{2}{*}{ AIV } & M52C & 5' CTTCTAACCGAGGTCGAAAG 3' & \multirow[t]{2}{*}{ Matrix gene $(M)$} & \multirow[t]{2}{*}{280} & \multirow{2}{*}{$\begin{array}{l}95 \mathrm{C} \text { for } 30 \mathrm{~s} ; 40 \text { cycles of } \\
95 \mathrm{C} \text { for } 30 \mathrm{~s}, 55 \mathrm{C} \text { for } 30 \mathrm{~s} \text {, } \\
72 \mathrm{C} \text { for } 30 \mathrm{~s} \text {; final extension } \\
\text { at } 72 \mathrm{C} \text { for } 1 \mathrm{~min}\end{array}$} & \multirow[t]{2}{*}[52]{} \\
\hline & & M253R & 5'AGGGCATITTGGACAAAKCGTCTA 3' & & & & \\
\hline \multirow{4}{*}{$\begin{array}{l}\text { Genotyping } \\
\text { PCR }\end{array}$} & \multirow[t]{2}{*}{ AIV } & HA-1134F & 5' GGAATGATHGAYGGNTGGTATG 3' & \multirow{2}{*}{$\begin{array}{l}\text { hemma-gglutinin } \\
\text { gene }(H A)\end{array}$} & \multirow[t]{2}{*}{600} & \multirow{2}{*}{$\begin{array}{l}95 \mathrm{C} \text { for } 30 \mathrm{~s} ; 40 \text { cycles of } \\
95 \mathrm{C} \text { for } 30 \mathrm{~s}, 55 \mathrm{C} \text { for } 30 \mathrm{~s} \text {, } \\
72 \mathrm{C} \text { for } 30 \mathrm{~s} \text {; final extension } \\
\text { at } 72 \mathrm{C} \text { for } 1 \mathrm{~min}\end{array}$} & \multirow[t]{2}{*}{ [53] } \\
\hline & & NS-890 R & 5' ATATCGTCTCGTATTAGTAGAAAC AAGG 3' & & & & \\
\hline & \multirow[t]{2}{*}{ IBV } & S15 & $5^{\prime}$ TGAAAACTGAACAAAAGACA 3' & \multirow[t]{2}{*}{ Spike gene (S) } & \multirow[t]{2}{*}{700} & \multirow{2}{*}{$\begin{array}{l}95^{\circ} \mathrm{C} \text { for } 2 \mathrm{~min} ; 40 \text { cycles } \\
\text { of } 95^{\circ} \mathrm{C} \text { for } 30 \mathrm{~s}, 52^{\circ} \mathrm{C} \\
\text { for } 30 \mathrm{~s}, 72^{\circ} \mathrm{C} \text { for } 30 \mathrm{~s} \text {; } \\
\text { final extension of } 72^{\circ} \mathrm{C} \\
\text { for } 12 \mathrm{~min}\end{array}$} & \multirow[t]{2}{*}{ [54] } \\
\hline & & CK2 & 5' CTCGAATTCCNGTRTTRTAYTGRCA 3' & & & & \\
\hline
\end{tabular}

$b p$ base pairs

${ }^{a}$ this primer pair does not detect serotype $C$ viruses

\section{Sequencing}

PCR products were purified using the NucleoSpin ${ }^{\circ}$ Gel and PCR Clean-up kit (Macherey-Nagel, Düren, Germany) following the manufacturer's instructions. Purified products were quantified with a Qubit ${ }^{\circledR} 2.0$ fluorometer (ThermoFisher Scientific, Waltham, CA). The PCR primers and $10 \mathrm{ng}$ of DNA were used for sequencing in both directions using a Big Dye Terminator v.3.1 cycle sequencing kit (Applied Biosystems) on a capillary sequencer (model 3100, Applied Biosystems). In case of nucleotide ambiguity, sequencing was repeated. Sequences generated in the present study were submitted to the EMBL/GenBank database under the accession numbers LT599493 to LT599497.

\section{Data analysis and phylogeny}

Assembly and analysis of sequence data were conducted using the BioEdit Software version 5.0.9 [44]. Additionally, the software was used to read the sequencing electrophoregrams and to exclude nucleotide ambiguity. To ensure the reliability of sequences, forward and reverse sequences were aligned with ClustalW [45]. Phylogenetic analyses were performed using the maximum likelihood method, the Tamura-Nei model (gamma distributed), with 500 bootstrap replicates and pairwise deletion using MEGA software Version 6.06 [46]. For reference, bootstrap values above 50 were labelled on major tree branches. The nucleotide sequences of partial segments of the S1, G, HA, and F genes of IBV, aMPV, AIV and AAVV-1, respectively, were compared with the first 10 blast hit sequences and reference sequences of the same genes from GenBank. Recent classifications for IBV genotypes were used [47].

\footnotetext{
Abbreviations

AAW-1: Avian Avulavirus/Newcastle disease virus; Alv: Avian influenza virus; aMPV: Avian metapneumovirus; APMV-1: Avian paramyxovirus 1; CDNA: Complementary DNA; CVRD: Common viral respiratory diseases; DNA: Deoxyribonucleic acid; dNTPS: Deoxynucleoside triphosphate; HA: Haemagglutination; IB: Infectious bronchitis; IBV: Infectious bronchitis virus; ILTV: Infectious laryngotracheitis virus; ND: Newcastle disease; OP: Oropharyngeal; PBS: Phosphate buffer saline; PCR: Polymerase chain reaction; RNA: Ribonucleic acid; SHS: Swollen head syndrome
}

\section{Acknowledgements}

The authors express special thanks to the participating farmers in Pakistan. We also thank the Plateau de Génomique GeT-Purpan, UDEAR UMR 5165 CNRS/UPS, CHU PURPAN, Toulouse, France, for the sequencing; Angelina Gorrill for editorial assistance; and Maxime Fusade-Boyer for his help with cartography. 


\section{Authors' contributions}

SU and HBA collected the samples and all the required data; SU and AT processed the samples; SU, MFD and JLG designed the study, analyzed and interpreted the data, and drafted the manuscript. All authors read and approved the final manuscript.

\section{Funding}

This study was funded by the Institut Carnot Santé Animale (ICSA), project RESPICARE. Sajid Umar's PhD scholarship was supported by the Higher Education Commission, Pakistan. The funding bodies did not play any role in design of the study, collection, analysis, and interpretation of data or in writing the manuscript.

\section{Availability of data and materials}

The datasets generated and/or analysed during the current study are not fully publicly available due to a confidentiality agreement on farms and farmers exact identification/location but raw laboratory datasets are available from the corresponding author on reasonable request.

\section{Ethics approval and consent to participate}

The Department of Veterinary Pathology, PMAS Arid Agriculture University Rawalpindi, Pakistan, ruled that no formal ethics approval was required to conduct this research (no ethical approval needed in Pakistan for animal sampling in the field). Before conducting the research, verbal informed consent was obtained from the owners or managers of the poultry farms included in this study. (No written consent was obtained as not all participants were literate; written consents are not compulsory for animal sampling).

\section{Consent for publication}

Not applicable.

\section{Competing interests}

The authors declare that they have no competing interests.

\section{Author details}

${ }^{1}$ IHAP, Université de Toulouse, INRA, ENVT, 23 Chemin des Capelles, 31076 Toulouse, France. ${ }^{2}$ PMAS Arid Agriculture University Rawalpindi, Rawalpindi, Pakistan. ${ }^{3}$ University of Veterinary \& Animal Sciences, Lahore, Pakistan.

Received: 18 July 2018 Accepted: 20 September 2019

Published online: 21 October 2019

\section{References}

1. Hussain J, Rabbani I, Aslam S, Ahmad HA. An overview of poultry industry in Pakistan. Worlds Poult Sci J. 2015;71:689-700.

2. Haq S. Poultry sector is spreading its wings. Express Trib. 2014; Available from: http://tribune.com.pk/story/741025/poultry-sector-is-spreading-its-wings/.

3. Usman M, Sarwar F, Umar S, Subhan S, Sohail ML, Younus M, et al. A clinical survey of viral respiratory diseases of commercial poultry in Pakistan. J Anim Plant Sci. 2017;27:2086-9

4. Ahmad I, Anjum MS, Hanif M. Prevalence of poultry diseases at high altitudes of district Poonch Azad Jammu \& Kashmir. Pak J Sci. 2012;64:334-6.

5. Rehman H, Fawad N, Abbas G, Naheed G, Siddique B, Afzal F, et al. Surveillance of poultry diseases in Punjab province, Pakistan; special reference to Newcastle disease. Res J Vet Pract. 2013;1:1-4.

6. Alam J, Muhammad F, Siddiqui MU, Khan SA, Rehmani S, Ahmad A. Dot ELISA for Newcastle disease, infectious Bursal disease and mycoplasmosis. Pak J Zool. 2012:44:1301-5.

7. Siddique AB, Rahman SU, Hussain I, Muhammad G. Frequency distribution of opportunistic avian pathogens in respiratory distress cases of poultry. Pak Vet J. 2012;32:386-9.

8. Abbas G, Khan S, Hassan M, Mahmood S, Naz S, Gilani S. Incidence of poultry diseases in different seasons in district Khushab, Pakistan. J Adv Vet Anim Res. 2015;2:141-5.

9. Umar S, Guerin JL, Ducatez MF. Low pathogenic avian influenza and coinfecting pathogens: a review of experimental infections in avian models. Avian Dis. 2017;61:3-15.

10. Chaudhry M, Angot A, Rashid HB, Cattoli G, Hussain M, Trovò G, et al. Reassortant avian influenza $\mathrm{A}(\mathrm{H} 9 \mathrm{N2} 2)$ viruses in chickens in retail poultry shops, Pakistan, 2009-2010. Emerg Infect Dis. 2015;21:673-6.
11. Ali M, Yaqub T, Mukhtar N, Imran M, Ghafoor A, Shahid MF, et al. Prevalence and phylogenetics of H9N2 in backyard and commercial poultry in Pakistan. Avian Dis. 2017;62:416-24.

12. Ali M, Yaqub T, Mukhtar N, Imran M, Ghafoor A, Shahid MF, et al. Avian influenza $A(H 9 N 2)$ virus in poultry worker, Pakistan, 2015. Emerg Infect Dis. 2019:25:136-9.

13. Naeem K, Naurin M, Rashid S, Bano S. Seroprevalence of avian influenza virus and its relationship with increased mortality and decreased egg production. Avian Pathol. 2003;32:285-9.

14. Iqbal M, Yaqub T, Reddy K, McCauley JW. Novel genotypes of H9N2 influenza A viruses isolated from poultry in Pakistan containing NS genes similar to highly pathogenic H7N3 and H5N1 viruses. PLoS One. 2009;4:e5788.

15. Sarwar M, Muhammad K, Rabbani M, Younus M, Sarwar N, Ali MA, et al. Prevalence of avian influenza viruses in live bird markets of Lahore. J Anim Plant Sci. 2013;23:388-92.

16. Munir M, Cortey M, Abbas M, Qureshi ZUA, Afzal F, Shabbir MZ, et al. Biological characterization and phylogenetic analysis of a novel genetic group of Newcastle disease virus isolated from outbreaks in commercial poultry and from backyard poultry flocks in Pakistan. Infect Genet Evol J Mol Epidemiol Evol Genet Infect Dis. 2012;12:1010-9.

17. Shabbir MZ, Abbas M, Yaqub T, Mukhtar N, Subhani A, Habib H, et al. Genetic analysis of Newcastle disease virus from Punjab, Pakistan. Virus Genes. 2013:46:309-15.

18. Farooq M, Saliha U, Munir M, Khan QM. Biological and genotypic characterization of the Newcastle disease virus isolated from disease outbreaks in commercial poultry farms in northern Punjab, Pakistan. Virol Rep. 2014;3-4:30-9.

19. Rahman A, Munir M, Shabbir MZ. A comparative genomic and evolutionary analysis of circulating strains of avian avulavirus 1 in Pakistan. Mol Gen Genomics. 2019. https://doi.org/10.1007/s00438-019-01580-w.

20. Wajid A, Dundon WG, Hussain T, Babar ME. Pathotyping and genetic characterization of avian avulavirus-1 from domestic and wild waterfowl, geese and black swans in Pakistan, 2014 to 2017. Arch Virol. 2018;163:2513-8.

21. Wajid A, Dimitrov KM, Wasim M, Rehmani SF, Basharat A, Bibi T, et al. Repeated isolation of virulent Newcastle disease viruses in poultry and captive non-poultry avian species in Pakistan from 2011 to 2016. Prev Vet Med. 2017;142:1-6.

22. Habib M, Yaqub T, Nazir J, Shehzad W, Aziz-Ul-Rahman, Sohail T, et al. Genomic and biological characterization of Newcastle disease viruses isolated from migratory mallards (Anas platyrhynchos). Arch Virol. 2018;163:2179-88.

23. Shabbir MZ, Nissly RH, Ahad A, Rabbani M, Chothe SK, Sebastian A, et al. Complete genome sequences of three related avian avulavirus 1 isolates from poultry farmers in Pakistan. Genome Announc. 2018;6:e00361-18.

24. Miller PJ, Haddas R, Simanov L, Lublin A, Rehmani SF, Wajid A, et al. Identification of new sub-genotypes of virulent Newcastle disease virus with potential panzootic features. Infect Genet Evol. 2015;29:216-29.

25. Ahmed Z, Naeem K, Hameed A. Detection and seroprevalence of infectious bronchitis virus strains in commercial poultry in Pakistan. Poult Sci. 2007;86: 1329-35.

26. Das SK, Khan MSR, Das M. Sero-prevalence of infectious bronchitis in chicken in Bangladesh. Bangladesh J Vet Med. 2009;7:249-52.

27. Sumi V, Singh SD, Dhama K, Gowthaman V, Barathidasan R, Sukumar K. Isolation and molecular characterization of infectious bronchitis virus from recent outbreaks in broiler flocks reveals emergence of novel strain in India. Trop Anim Health Prod. 2012;44:1791-5.

28. Najafi H, Langeroudi AG, Hashemzadeh M, Karimi V, Madadgar O, Ghafouri SA, et al. Molecular characterization of infectious bronchitis viruses isolated from broiler chicken farms in Iran, 2014-2015. Arch Virol. 2016;161:53-62.

29. Seger W, GhalyanchiLangeroudi A, Karimi V, Madadgar O, Marandi MV, Hashemzadeh M. Genotyping of infectious bronchitis viruses from broiler farms in Iraq during 2014-2015. Arch Virol. 2016;161:1229-37.

30. Rahimi M. Seroprevalence of avian metapneumovirus infection in broiler and broiler breeder chickens in Iran. Vet Med. 2011;56:395-9.

31. Mayahi M, Seifi MR, Pourmehdi M, Seyyedkolaei SJG. Serological study on avian Metapneumovirus in boiler chicks by ELISA test. 3rd Int. Vet. Poult. Tehran, Iran; 2012

32. Eswaran MA, Sukumar K, Rajeswar JJ, Balasubramaniam GA, Anna T. Serological survey of avian metapneumovirus infection in broiler breeder chicken farms in Tamil Nadu. Int J Adv Vet Sci Technol. 2014;0:84-7.

33. Hosseini $H$, Ghalyanchi-Langeroudi A. Detection and molecular characterization of avian metapneumovirus in Iran: the first report. Iran J Virol. 2012;6:26-31. 
34. Homayounfar N, Shoushtari H, Charkhkar HSS, Bozorgmehrifard M. Detection by reverse transcriptase-polymerase chain reaction and molecular characterization of avian metapneumovirus in chicken flocks in Iran. WALIA J. 2015:31:170-4.

35. Owoade AA, Ducatez MF, Hübschen JM, Sausy A, Chen H, Guan Y, et al. Avian metapneumovirus subtype $A$ in China and subtypes $A$ and $B$ in Nigeria. Avian Dis. 2008;52:502-6.

36. Wei L, Zhu S, Yan X, Wang J, Zhang C, Liu S, et al. Avian metapneumovirus subgroup C infection in chickens, China. Emerg Infect Dis. 2013;19:1092-4.

37. Sun S, Chen F, Cao S, Liu J, Lei W, Li G, et al. Isolation and characterization of a subtype $\mathrm{C}$ avian metapneumovirus circulating in Muscovy ducks in China. Vet Res. 2014;45:74.

38. Shabbir MZ, Zohari S, Yaqub T, Nazir J, Shabbir MA, Mukhtar N, et al. Genetic diversity of Newcastle disease virus in Pakistan: a countrywide perspective. Virol J. 2013:10:170

39. Shanmuganatham K, Feeroz MM, Jones-Engel L, Smith GJD, Fourment M, Walker $\mathrm{D}$, et al. Antigenic and molecular characterization of avian influenza A(H9N2) viruses, Bangladesh. Emerg Infect Dis. 2013;19:1393-402.

40. Costa-Hurtado M, Afonso CL, Miller PJ, Spackman E, Kapczynski DR, Swayne DE, et al. Virus interference between H7N2 low pathogenic avian influenza virus and lentogenic Newcastle disease virus in experimental co-infections in chickens and turkeys. Vet Res. 2014;45:1.

41. França M, Howerth EW, Carter D, Byas A, Poulson R, Afonso CL, et al. Coinfection of mallards with low-virulence Newcastle disease virus and lowpathogenic avian influenza virus. Avian Pathol. 2014;43:96-104.

42. Gilbert M, Nicolas G, Cinardi G, Van Boeckel TP, Vanwambeke SO, Wint GRW, et al. Global distribution data for cattle, buffaloes, horses, sheep, goats, pigs, chickens and ducks in 2010. Sci Data. 2018;5:180227.

43. Robinson TP, Wint GR, Conchedda G, Van Boeckel TP, Ercoli V, Palamara E, et al. Mapping the global distribution of livestock. PLoS One. 2014;9(5):e96084.

44. Hall T. BioEdit: a user-friendly biological sequence alignment editor and analysis program for windows 95/98/NT. Nucleic Acids Symp Ser. 1999;41:95-8.

45. Chenna R, Sugawara H, Koike T, Lopez R, Gibson TJ, Higgins DG, et al. Multiple sequence alignment with the Clustal series of programs. Nucleic Acids Res. 2003;31:3497-500.

46. Tamura K, Peterson D, Peterson N, Stecher G, Nei M, Kumar S. MEGA5: molecular evolutionary genetics analysis using maximum likelihood, evolutionary distance, and maximum parsimony methods. Mol Biol Evol. 2011;28:2731-9.

47. Valastro V, Holmes EC, Britton P, Fusaro A, Jackwood MW, Cattoli G, et al. S1 gene-based phylogeny of infectious bronchitis virus: an attempt to harmonize virus classification. Infect Genet Evol. 2016;39:349-64.

48. Kho CL, Mohd-Azmi ML, Arshad SS, Yusoff K. Performance of an RT-nested PCR ELISA for detection of Newcastle disease virus. J Virol Methods. 2000;86:71-83.

49. Farsang A, Ros C, Renström LH, Baule C, Soós T, Belák S. Molecular epizootiology of infectious bronchitis virus in Sweden indicating the involvement of a vaccine strain. Avian Pathol. 2002;31:229-36.

50. Humberd J, García M, Riblet SM, Resurreccion RS, Brown TP. Detection of infectious laryngotracheitis virus in formalin-fixed, paraffin-embedded tissues by nested polymerase chain reaction. Avian Dis. 2002:46:64-74.

51. Juhasz K, Easton AJ. Extensive sequence variation in the attachment (G) protein gene of avian pneumovirus: evidence for two distinct subgroups. J Gen Virol. 1994;75:2873-80.

52. Fouchier RA, Bestebroer TM, Herfst S, Van Der Kemp L, Rimmelzwaan GF, Osterhaus AD. Detection of influenza A viruses from different species by PCR amplification of conserved sequences in the matrix gene. J Clin Microbiol. 2000;38:4096-101.

53. Phipps LP, Essen SC, Brown $\mathbb{H}$. Genetic subtyping of influenza A viruses using RT-PCR with a single set of primers based on conserved sequences within the HA2 coding region. J Virol Methods. 2004;122:119-22.

54. Gelb J Jr, Weisman Y, Ladman BS, Meir R. S1 gene characteristics and efficacy of vaccination against infectious bronchitis virus field isolates from the United States and Israel (1996 to 2000). Avian Pathol. 2005:34:194-203.

\section{Publisher's Note}

Springer Nature remains neutral with regard to jurisdictional claims in published maps and institutional affiliations.

Ready to submit your research? Choose BMC and benefit from:

- fast, convenient online submission

- thorough peer review by experienced researchers in your field

- rapid publication on acceptance

- support for research data, including large and complex data types

- gold Open Access which fosters wider collaboration and increased citations

- maximum visibility for your research: over $100 \mathrm{M}$ website views per year

At BMC, research is always in progress.

Learn more biomedcentral.com/submissions 